Journal of Engineering and Applied Sciences 14 (12): 4116-4123, 2019

ISSN: $1816-949 \mathrm{X}$

(C) Medwell Journals, 2019

\title{
The Role of Internal Audit in Auditing the Strategic Plan of the Organization using Strategic Audit: An Applied Research in the State Company for Rubber Industries and Tires
}

\author{
${ }^{1}$ Razzaq Sadeq Razzaq and ${ }^{2}$ Ali Mohammed Thijeel \\ ${ }^{1}$ Institute for Accounting and Financial Studies, \\ ${ }^{2}$ Institute for Accounting and Financial Studies, Department of Accounting Studies, \\ University of Baghdad, Baghdad, Iraq
}

\begin{abstract}
The changes in the internal and external business environment have created risks that may impede the achievement of the strategic objectives of the organizations, thus, it's threaten their survival and continuity. So, the role of the organization's control should be activated to limit the effects of these risks. This role has become an internal audit function. While the internal audit departments are deficient in auditing many aspects of the organization's activities including studying and analyzing the external environment of the organization to determine the strategic situation of the organizations in order to achieve that we must develop the procedures and programs internal audit work and expand the scope of research. The study aimed to demonstrate the impact of the use of strategic audit on increasing the role of internal audit. Also, the study adopted SWOT analysis on the sample of the study which is the company for Rubber Industries and Tires in Iraq. The study concluded that the internal audit plays a major role in the strategic plan auditing of the company when the internal auditors use the steps and procedures of the strategic audit. Besides, they will have the vision and insight in the strategic position and also, the ability to identify the appropriate strategy of the company.
\end{abstract}

Key words: Internal audit, strategic audit, strategic plan, strategic situation, SWOT analysis, company environment

\section{INTRODUCTION}

Due to the great expansion of the volume of business and also, major developments in the financial and administrative fields, the increase in competition among companies and the increase in the risks volume of surrounding them due to the rapid economic, political and technological changes, the role of internal auditing shifted from the traditional role of detecting errors and irregularities in financial operations to management consolidation, corporate governance, participation in risk management evaluation and provision of consulting and insurance services to achieve the management efficiency. Achieving that requires increasing in the internal audit procedures and scope to include auditing and studying of the company's strategic plans and its policies in order to verify the compatibility of strategic plans with the strategic position of the company which requires the adoption of new methods and trends in the audit process. Therefore, the problem of the study is that, the scope of the internal audit departments is not including verifying the suitability of these strategic plans with the current and future strategic situation of the organization.

Research objective: The importance of strategic auditing as an effective tool in enhancing the role of the companie's internal audit by studying the internal and external environment to identify the strengths, weaknesses, opportunities and threats which enables the internal auditors ability to have a future vision for verify the compatibility of the prepared strategic plan with the current and future strategic position of the company, so, the research aims to achieve the following objectives:

Discussing the concepts of internal auditing and strategic auditing

Determining the impact of using the steps and tools of strategic audit in increasing the role of internal audit

Corresponding Author: Razzaq Sadeq Razzaq, Institute for Accounting and Financial Studies, University of Baghdad, Baghdad, Iraq 
This research is based on the assumption that the role of internal audit departments increase when they audit the organization's strategic plan using strategic audit.

\section{Literature review}

Internal audit concept: The developments in the objectives and nature of internal audit have led to many changes in definitions and the concept of internal audit. Prior the basic task of internal audit was represented by clerical function (Pickett, 2011). Then the internal audit role was expanded to serve as a tool for management to verify compliance with the internal control system. So, it was defined as an "administrative tool to assess how executive management exercised control systems" (Al-Din and Fayed, 2015).

Next, the internal audit role has developed to a contemporary approach which provide assurance and consulting services (Selim and McNamee, 1999). After that, the Institute of Internal Auditors (IIA) issued a new guide to the practice of internal auditing that includes a definition of internal audit as "Internal auditing is an" "independent, objective assurance and consulting activity designed to add value and improve an organization's operations. It helps an organization accomplish its objectives by bringing a systematic, disciplined approach to evaluate and improve the effectiveness of risk management, control and governance processes" (Gantz, 2013). This definition focused on the strategic role of the internal auditor within the organization and also, the significant shift in its scope from error detection to assessment of risk management practices (Al Shamsi, 2018).

Strategic audit: The strategic audit defined as "a systematic, structured and comprehensive review of strategy and strategic processes to identify weaknesses, blind spots, reasons why profits are failing to reach predicted levels and new areas where potentially far more value can be added" (Grundy, 2007). This definition focused on the study of the causes of failure of the organization and the failure to achieve profits.

And it also defined as "The process of systematic examination and evaluation of the strategic position of business organizations which is comprehensive in terms of analysis of internal environmental factors and external environmental factors, selection processes and strategic implementation to provide recommendations and suggestions for management in the strategic decisionmaking process and to ensure that the organization continues to add value by verifying the efficiency and effectiveness of the organization's management in the use of its economic resources and the achievement of its strategic objectives". This definition is more comprehensive that ensures an examination of internal and external environmental factors and also, helps enabling management to make strategic decisions or to evaluate decisions taken in a manner consistent with the organization's environment.

Strategic auditing can be classified into internal and external strategic auditing, internal strategic audit requires identifying the strengths and weaknesses within the organization in order to verify the use of strengths to focus on it and diagnoses weaknesses and providing recommendations and actions to treat it (Lehtonen and Sipila, 2007). External strategic audit refers to examine the external environment surrounding the organization to identify opportunities and threats to the organization (Hohmann, 2013). Therefore, strategic auditing is an important tool for senior management. It helps management in the decision making process by providing the necessary information in a timely manner. It also gives a comprehensive view of the organization which enables it to carry out the comprehensive evaluation of its strategic position. As well as (David) states that strategic audit can be performed by three groups: auditors, government auditors and internal auditors (David, 2001).

Relationship between internal audit and strategic audit the role of strategic audit in the internal audit effectiveness: The recent developments in the internal audit function were accompanied by the development of the objectives and procedures of the internal audit after the development of the senior management's thought in looking at the internal audit, the senior management involve internal audit to review the organization's strategy in order to participate them in the provision of consultancy with a strategic dimension which required to develop the level of procedures, tools and methods adopted by the internal audit.

The concept of strategic auditing has emerged according to request of the Institute of internal auditors for the purpose of defending the measurement methods used by internal auditors to ascertain the extent of strategic plan adherence of the organization. The institute has emphasized that the internal auditor must has an insight and a future perspective to support the organization because the 
Table 1: International Internal Audit Standards amendment

Standard title/Standard No.
Managing the internal audit activity
and
Planning
2010

Nature of work

2100

Governance

2110

2110. A1

2110.A2

Engagement planning

2200

Planning considerations

2201

Engagement objectives

2210

whether

with

laws

Overall opinions

2450

\section{The addition on the standar}

The internal audit activity adds value to the organization and its stakeholders when it considers strategies, objectives, and risks; strives to offer ways to enhance governance, risk management and control processes objectively provides relevant assurance

To develop the risk-based plan, the chief audit executive consults with senior management and the board and obtains an understanding of the organization's strategies, key business objectives, associated risks and risk management processes. The chief audit executive must review and adjust the plan as necessary in response to changes in the organization's business, risks, operations, programs, systems and controls

Internal audit credibility and value are enhanced when auditors are proactive and their evaluations offer new insights and consider future impact

The internal audit activity must assess and make appropriate recommendations to improve the organization's governance processes for:

Making strategic and operational decisions

Overseeing risk management and control

The intemal audit activity must evaluate the design, implementation and effectiveness of the organization's ethics-related objectives, programs and activities

The internal audit activity must assess whether the information technology governance of the organization supports the organization's strategies and objectives

The plan must consider the organization's strategies, objectives and risks relevant to the engagement

In planning the engagement, internal auditors must consider. The strategies and objectives of the activity being reviewed and the means by which the activity controls its performance

Adequate criteria are needed to evaluate governance, risk management and controls. Internal auditors must ascertain the extent to which management and/or the board has established adequate criteria to determine objectives and goals have been accomplished. If adequate, internal auditors must use such criteria in their evaluation. If inadequate, internal auditors must identify appropriate evaluation criteria through discussion management and/or the board. Internal (e.g., policies and procedures of the organization). External (e.g., and regulations imposed by statutory bodies). Leading practices (e.g., industry and professional guidance)

When an overall opinion is issued it must take into account the strategies, objectives and risks of the organization

implementation of its strategic plans cannot be achieved in the short term but requires long periods as well as when internal auditors wait for achieving plan, the importance of auditing may be lost (Ghalbi as., 2007).

Development of Internal Auditing Standards towards strategic audit: In October 2016, the International Internal Audit Standards Board revised its Internal Audit Standards as part of responding to the recent events of financial crises and economic changes. The amendment included an evolution of the role of internal audit, through the addition of a new strategic audit role. The new revised version requires the internal auditor to take into consider organizational objectives and strategies when planning and implementing the internal audit function, so as to enable them to have insight and proactive focus on the future of the organization. Table 1 shows the amendment on the International Internal Audit Standards as follows (IIA., 2016). From Table 1, we observe that the American Institute of Internal Auditors has focused on the objectives and strategies of the organization when amending the standards. It considered that internal auditing does not add value to the organization, unless it takes into account its objectives and strategies. And also to verify the organization processes are compatible with these strategies and objectives. According to this, the internal auditors will be able to have the vision of the organization's future, moreover, the amended standards allowed them to study internal and external organization environment in order to have the ability of auditing the organization's strategic position.

\section{MATERIALS AND METHODS}

This study is divided into two main parts: Studying the company's strategic plan and the strategic position of it through SWOT analysis. The empirical study will be applied to the sample of the study, the state company for Rubber Industries and Tires in Iraq for the years 2014-2017. The data will be collected from the financial, managerial and statistical records as well as the adoption of surveys questionnaire and interviews. 
J. Eng. Applied Sci., 14 (12): 4116-4123, 2019

Table 2: Actual production for the year 2017 and planned production for the years (2018-2022)

\begin{tabular}{|c|c|c|c|c|c|c|}
\hline \multirow[b]{2}{*}{ Products } & \multirow{2}{*}{$\begin{array}{l}\text { Actual production } \\
-2017 \\
\end{array}$} & \multicolumn{5}{|c|}{ Planned production } \\
\hline & & 2018 & 2019 & 2020 & 2021 & 2022 \\
\hline Tires & 9618 & 153272 & 160936 & 168982 & 527431 & 686303 \\
\hline Rubber goods & 5550 & 6300 & 6615 & 6946 & 7293 & 7658 \\
\hline Hoses & - & 160000 & 168000 & 176400 & 185220 & 194481 \\
\hline Crushed rubber & 40.5 & 68 & 71 & 75 & 79 & 83 \\
\hline
\end{tabular}

Strategic plan of the company for Rubber Industries and Tires in Iraq for the years (2018-2022)

Research method: In this study we'll use (SWOT) analysis it defines as "a tool that helps you evaluate the Strengths, Weaknesses, Opportunities and Threats (SWOT) involve in any business enterprise" (Anonymous, 2008). So, it's an investigative tool for current situation of an organization in a certain time. in forward-looking manner depending on the past and current events and data as well as, analyze the structure taking into account the organization prospective, at the same time, the SWOT analysis focuses on the internal environment (Strength and Weakness) and on the external environment (Opportunities and Threats) of an organization (Speth and Probert, 2015) in the (SWOT) the column distinguish between factors that are helpful and those that are harmful in respect of your (SWOT) objectives (Sarsby, 2016):

. Helpful factors: are those that assist your success, like strengths and opportunities

- Harmful factors: are those that impede or block your success, like weaknesses and threats

Studying the company's strategic plan: Through the study of the strategic plan prepared by the company for the years (2018-2022) were determined strategic direction of the company by diagnosing the following: expansion of the production plan for its products, despite the failure to achieve the production plan and the decrement in sales for the past 4 years. Table 2 shows this from the Table 2, we didn't observe a preparation of a new marketing plan compatible with the increase in the volume of planned production for the next 5 years such as increasing in advertising campaigns and promote their products. The strategic plan included the increase in investments by purchasing a new production lines in an attempt to achieve growth and expansion without conducting market studies and economic feasibility as follows:

Production line of high density polyethylene pipes for health facilities with an annual design capacity of $(600000 \mathrm{~m})$
Production line of (UPVC pipes) for sewer networks with annual design capacity of $(600000 \mathrm{~m})$

- Production line of plastic waste bags with a capacity of (600) tons/year

So, based on the above, the study revealed that the company has followed the expansion and growth strategy (Aggressive) without taking into account the corrective measures to treat the problems and obstacles as well as avoid the risks that threaten the company.

Studying the company's strategic position through (SWOT) analysis: In order to determine an appropriate company strategy the organization's strategic situation will be studied through three stages namely, diagnosis, analysis and recommendations as detailed.

Diagnosis and analysis stages: After collecting information and data from the internal and external environment of the company the internal and external factors were identified and classified in to four classes: Strengths, Weaknesses, Opportunities and Threats then we'll analyze these factor using (SWOT) analysis as follows:

Internal factors: The evaluation of the internal environment of the company aims to identify the strengths and weaknesses points. And when evaluating the internal environment of the company the most important aspects of the company were detected and categorized, the Table 3 shows that. The Table 3 , shows that the total company strengths of these factors amounted to (6) points out of the total points of (27) points which represents (22\%) and the rest amounted (21) points weaknesses which represents $(78 \%)$, So, the results indicate obviously that the company's weaknesses are greater than its strengths. Therefore, the company must take corrective and proper procedures to reduce the weaknesses and work to gain new strengths that would improve internal situation of the company (Fig. 1). 
Table 3: Evaluation of internal factors of the company

\begin{tabular}{|c|c|c|}
\hline \multirow{2}{*}{\multicolumn{3}{|c|}{$\begin{array}{l}\text { Internal factors/Details } \\
\text { Human resources }\end{array}$}} \\
\hline & & \\
\hline The high number of employees with engineering competencies & $\mathrm{X}$ & \\
\hline The high number of employees with intermediate or lower degrees & & $\mathrm{X}$ \\
\hline The high number of employees over the age of (50) years & & $\mathrm{X}$ \\
\hline Low participation of staff in training and development courses & & $\mathrm{X}$ \\
\hline \multicolumn{3}{|l|}{ Financial resource } \\
\hline Concentration of production costs in salaries and wages of workers & & $\mathrm{X}$ \\
\hline The scarcity of raw materials & & $\mathrm{X}$ \\
\hline Slow inventory turnover for long periods & & $\mathrm{X}$ \\
\hline Decreasing sales volume & $\mathrm{X}$ & \\
\hline The inflation in the ratio of accumulated deficit, loans to the capital & & $\mathrm{X}$ \\
\hline The company's working capital is negative & $\mathrm{X}$ & \\
\hline Increase the percentage of the need for loans & & $\mathrm{X}$ \\
\hline An evolution in the company's plant assets & & $\mathrm{X}$ \\
\hline Low utilization of the company's assets & & $\mathrm{X}$ \\
\hline Aging of plant assets in time and technology & & $\mathrm{X}$ \\
\hline Inability of the company to provide the liquidity to meet its obligations & & $\mathrm{X}$ \\
\hline \multicolumn{3}{|l|}{ Production } \\
\hline A significant reduction in the utilization rates of design capacities & & $\mathrm{X}$ \\
\hline Decrease in the number of days of utilization of production lines & & $\mathrm{X}$ \\
\hline A significant decline in the development of production ratios & & $\mathrm{X}$ \\
\hline A positive deviation of quantities of raw materials in production & $\mathrm{X}$ & \\
\hline Efficiency of workers in the production lines & $\mathrm{X}$ & \\
\hline \multicolumn{3}{|l|}{ Marketing } \\
\hline A decrease in the company's ability to market its products & & $\mathrm{X}$ \\
\hline $\begin{array}{l}\text { Lack of channel of distribution in the local markets and limiting them to } \\
\text { the company's headquarters and factories }\end{array}$ & & $\mathrm{X}$ \\
\hline Lack of using the modern methods of marketing & $\mathrm{X}$ & \\
\hline After sales warranty service is available & & $\mathrm{X}$ \\
\hline Lack of using the modern methods of advertising and promotion & & $\mathrm{X}$ \\
\hline \multicolumn{3}{|l|}{ R\&D } \\
\hline Lack of interest in research and development & & $\mathrm{X}$ \\
\hline Benefiting from the applications of scientific research in the company & $\mathrm{X}$ & \\
\hline Total & 6 & 21 \\
\hline
\end{tabular}

Table 4: Evaluation of internal factors of the company

External factors/Details $\quad$ Opportunities

Political factors

The decision to merge the industrial companies

The decision to raise the price of fuel

The decision to return separated from job

Providing loans and grants to assist the company

Investment of Iraqi rubber plantations in Vietnam

The decision to dispose of the consumed tires of the government institutions

and send them to the company for recycling

Economical factors

The negative value of adding value to the national product

The negative impact of the company on the payments balance

$\mathrm{x}$

Increasing demand for tires

$\mathrm{X}$
$\mathrm{X}$

Using of machines and equipment designed for the manufacture of modern radial tires

Never change technological course by changing some of materials used in production

which reduces the weight and cost of the product

Environmental factors

The company's location near the refinery of oil

The possibility of rubber cultivation in the territories

$\mathrm{X}$
$\mathrm{X}$
$\mathrm{X}$

Legal factors

The national product protection act is not enforced

Social factors

One of the company's factories located in the middle of the residential areas in the

province, may claims by population to stop it

Total

External factors: The external factors are opportunities and threats. Table 4 shows the external factors categorized into opportunities and threats as follows: the Table 4 shows that the total company opportunities of these factors amounted to 7 points out of the total points of 19 points which represents
(37\%) and the rest amounted (12) points threats which represents $(63 \%)$, so, the results indicate obviously that the company's threats are greater than its opportunities. That means there are many potential threats to the strategic plan that the company must face in order to be able to control its external 


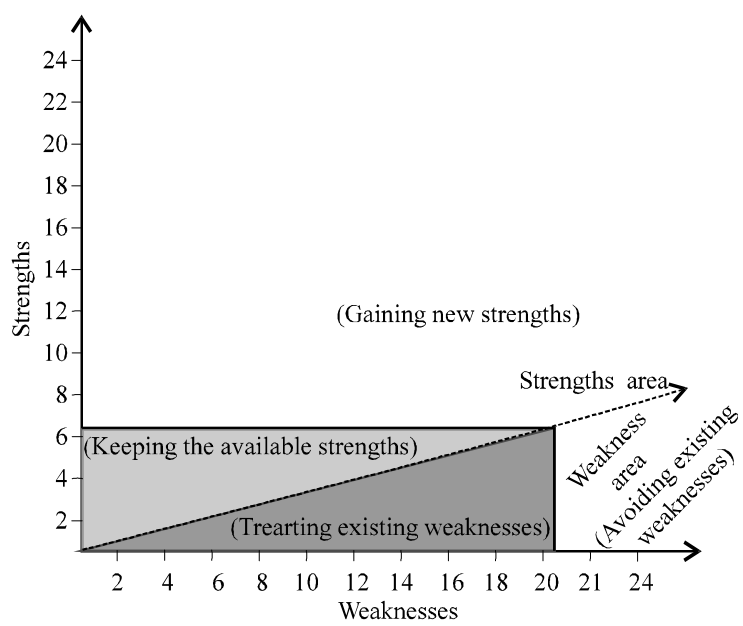

Fig. 1: Internal environment of company; the current and future strategic position of the cmpany

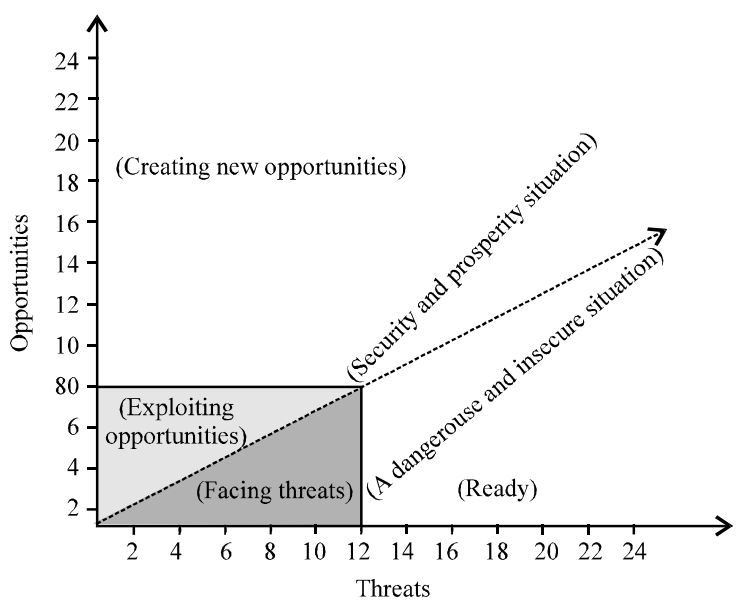

Fig. 2: External environment of company; the current and future strategic position of the cmpany

environment. Therefore, it must adapt to these threats and to reduce their effects. In contrast, make efforts to exploit opportunities within the external environment (Fig. 2).

Internal and external factors analysis using (SWOT) matrix: To determine the type of strategy must be followed by the company, the strategic position will be determined using the internal and external environment analysis matrix. It's a tool called internal-external matrix is used to determine the strategic position of company (Sarsby, 2016). By assessing the internal environment of the company from Table 3 , the internal environment of the company is found to be weak. Table 4 shows the company's external environment high threats the internal and external environment matrix highlights the
Internal environment

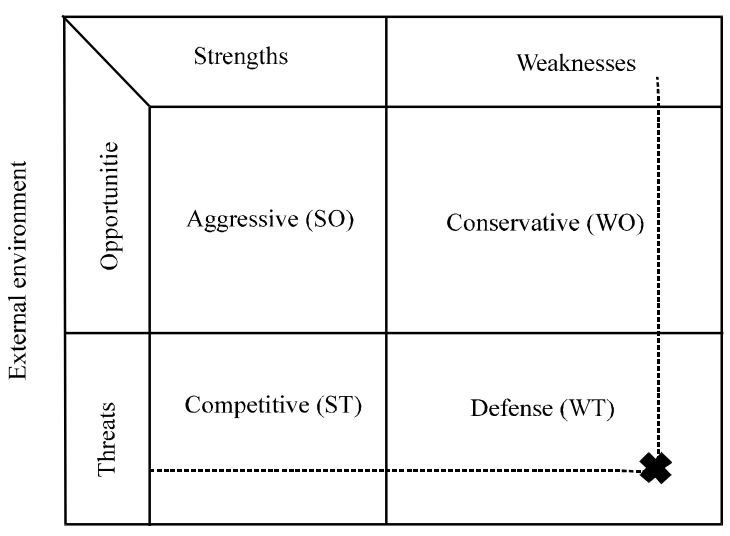

Fig. 3: Internal-external environment matrix

proportional area of strategies in the (SWOT) framework as in Fig. 3. From Fig. 3 it's obvious that the appropriate strategy of the company should be a defensive strategy (WT). The company could face several threats from the external environment, at the same time they are several weaknesses of internal environment, making it in a very critical position may be subject to liquidation. It requires treating internal weaknesses to reduce external threats, besides, reduce the volume of the company's activity level as low as possible, so as to reduce expenses and thus reduce the size of losses.

Recommendations stage: The necessity of taking into consideration the current and future strategic position of the company before developing the strategic plan through perform strategic analysis for the company's environment using (SWOT) analysis. The necessity of adopting defense strategy instead of aggressive strategy in order to maintain its continuity and sustainability by focusing on the strengths and development and treating the weaknesses in the one hand, exploit opportunities and avoid potential threats on the other hand, we can achieve that through the following actions.

Reviewing the company's management philosophy and the adopted strategy. Promote the efficiency of the employees of the company by developing their scientific and professional level. Reducing the number of employees as low as level and as needed. Reducing the production and administrative costs by rationalizing costs. Increasing production quality in addition to focus on one product rather than dispersion in product types. Disposing of stopped production lines and machine and also useless assets, by selling them to participate solve liquidity problems (Anonymous, 2008, 2016). 


\section{RESULTS AND DISCUSSION}

Test hypothesis: The results of the research in paragraph (4.1-2) showed that using of the strategic audit by internal auditors help them to study and evaluation the strategic position of the company. However by using (SWOT) analysis, the suitable strategy for company has been determined. The internal auditors have been able to assess the suitability of the strategic plan prepared by the company with the current and future position of the company. Apparently, they become able to recommend about adopting defense strategy instead of aggressive strategy, so, they have a future and proactive vision and insight in audit, besides, giving them many abilities and awareness in providing consultant and assurance opinions to the senior management. Based on above, we can prove the hypothesis saying "The role of Internal Audit Department's increase when they audit the organization's strategic plan using strategic audit"

\section{CONCLUSION}

This study revealed that the internal audit plays a major role in the audit of the company's strategic plan by using the steps and procedures of the strategic audit. So, the internal audit will have the ability to determine the suitability of the company's strategic plan with its strategic position. Moreover, internal auditing adds more value to the company when it takes into accounting the company's objectives and strategies before planning and implementing the internal audit process. As well as, reviewing and analyzing the internal and external environment of the company by the internal auditors and studying company's strategic position, gives them the ability to have a future vision that increases its ability to anticipate risks. The results of our study of the company's strategic plan for the period 2018-2022 showed that the company followed the strategy aggressive in its activity without taking into account the current and future strategic situation while the results of the strategic analysis of the company showed that the defensive strategy is the most appropriate strategy because of the company's weakness in the internal environment and the threats in the external environment. If not adopted, the company may face the risk of bankruptcy and liquidation in the future.

\section{RECOMMENDATIONS}

The internal audit departments should audit the company's strategic plan through using of the strategic audit and its tools in addition to expand the scope of the internal audit to include the external environment of the company besides, its internal environment. Taking into consider the company's objectives and strategies when planning and implementing the internal audit process. The internal audit departments should review, study the company's internal and external environment to determine the factors influencing the performance of the company such as (management philosophy, organizational structure, economic factors, political factors, technological factors) then analyze them to determine their impact on future plans in order to avoid the potential problems. Taking into consideration the current and future of the company's strategic situation when developing the strategic plan through performing strategic analysis for the internal and external environment of the company. The need for the company to change its strategic thinking, management philosophy and adopt a defensive strategy when developing the strategic plan in order to maintain its sustainability and continuity.

\section{REFERENCES}

Al Shamsi, A., 2018. [The evolution and importance of internal audit]. Internal Auditors Association, Dubai. UAE. (In Arabic) https://translate.google. com/ translate?hl=en\&sl=ar\&u=http://www.internalaudit or.me/ar/article/the-evolution-importance-of-interna 1-audit/\&prev $=$ search

Al-Din, N. and A. Fayed, 2015. Accounting Auditing in Accordance with International Standards. Dar Al-Janan Publishing and Distribution, Amman, Jordan,

Anonymous, 2008. SWOT analysis a tool for making better business decisions. United States Department of Agriculture, Washington, D.C., USA.

Anonymous, 2016. The concept of insight in auditing. Baker Tilly International, London, UK.

David, F.R., 2001. Strategic Management Concept and Cases. 8th Edn., Prentice Hall, Upper Saddle River, New Jersey, USA., ISBN:9780130269959, Pages: 432.

Gantz, S.D., 2013. The Basics of IT Audit: Purposes, Processes and Practical Information. Elsevier, Amsterdam, Netherlands, USA., ISBN:9780124171596, Pages: 270.

Ghalbi, A., T. Mohsen and W.M. Idris, 2007. Strategic Management. 1st Edn., Dar Wael Publishing, Amman, Jordan, Pages: 469.

Grundy, T., 2007. Strategic Audit: Why its Vital to Give your Strategy a Health Check?. Cengage Learning, Boston, Massachusetts, USA.,.

Hohmann, C., 2013. Telenium-gaining knowledge in the German IT market: Chances and risks: A case study. Master Thesis, Technical University of Madrid, Madrid, Spain. 
IIA., 2016. International standards for the professional practice of internal auditing (Standards). The Institute of Internal Auditors, Lake Mary, Florida, USA. https://na.theiia.org/standards-guidance/mandator y-guidance/pages/standards.aspx

Lehtonen, H. and L. Sipila, 2007. Competitor analysis and strategic marketing planning in a HVAC company. BA Thesis, School of Business, Rauma, Finland.

Pickett, K.H.S., 2011. The Essential Guide to Internal Auditing. 2nd Edn., John Wiley \& Sons, Hoboken, New Jersey, USA., ISBN:9781119973829, Pages: 384 .
Sarsby, A., 2016. SWOT Analysis: A Guide to SWOT for Business Studies Students. Lulu Press, Morrisville, North Carolina, USA., ISBN: 9780993250422 , Pages: 75.

Selim, G. and D. McNamee, 1999. Risk management and internal auditing: What are the essential building blocks for a successful paradigm change?. Intl. J. Aud., 3: 147-155.

Speth, C. and C. Probert, 2015. The SWOT Analysis: Develop Strengths to Decrease the Weaknesses of your Business. 50Minutes.com, New York, USA., ISBN:9782806269324, 